\title{
Evidence that phospholipid protects ram spermatozoa from cold shock at a plasma membrane site
}

\author{
P. J. Quinn, P. Y. W. Chow* and I. G. White*
}

Department of Biochemistry, Chelsea College, University of London, London SW3 6LX, U.K. and ${ }^{*}$ Department of Veterinary Physiology, University of Sydney, Sydney 2006, Australia

\begin{abstract}
Summary. Adding phospholipid dispersions to washed ram spermatozoa provided immediate protection against cold shock as judged by the effect on motility. Re-washing the spermatozoa free of dispersed lipid rendered then susceptible to cold shock. Analysis of the spermatozoa showed that exogenous phospholipid had not become interpolated into the cell membranes. The ratio of phospholipid to cholesterol in the spermatozoon was not changed when dispersed phospholipid was added and stayed the same during incubation for $3 \mathrm{~h}$ at $37^{\circ} \mathrm{C}$. It is concluded that the protective effect of phospholipid against cold shock in ram spermatozoa is due to a 'loose' interaction of the lipid structures with the plasma membrane of the cells.
\end{abstract}

\section{Introduction}

It is well known that the spermatozoa of many animals, including rams, undergo irreversible changes when cooled rapidly between about 15 and $0^{\circ} \mathrm{C}$. There is failure to regain full metabolic activity and motility when rewarmed because of the disruption of cell membranes and the loss of intracellular constituents (see Quinn, White \& Cleland, 1969). The precise mechanism that gives rise to the primary lesion is unknown but there is much evidence suggesting that breakdown in the permeability properties of the plasma membrane is an early event in the process. Several studies have indicated that the composition of the sperm membranes is related to susceptibility of the cells to cold shock, particularly the lipid constituents. Thus, spermatozoa from species which have a high ratio of polyunsaturated : saturated fatty acyl residues associated with the membrane phospholipids tend to be more susceptible to cold shock (Poulos, Darin-Bennett \& White, 1973; Darin-Bennett, Poulos \& White, 1974). Furthermore, susceptibility to cold shock has also been correlated with the ratios of cholesterol : phospholipid (Darin-Bennett \& White, 1977).

Phospholipids, including those present in egg yolk, are almost invariably included in semen diluents to protect the spermatozoa from cold shock, but the nature of the protective action of these lipids is unclear (Blackshaw, 1954a). Several explanations may be considered. Firstly, fusion of phospholipid vesicles with the sperm membranes or interpolation of individual phospholipids into these membranes may increase the phospholipid to protein and cholesterol ratios or alter the ratio of polyunsaturated:saturated lipids of the membrane. Secondly, the exogenous phospholipid structures may extract cholesterol from the cell membranes as they have been shown to do in other systems (Bruckdorfer, Graham \& Green, 1968; Madden, Chapman \& Quinn, 1979), thereby altering the ratio of cholesterol to phospholipid in the membrane. Finally, phospholipid structures may simply bind reversibly to the cell membrane surface, causing rearrangement of the membrane constituents. The present study was undertaken to examine the way exogenous phospholipid protects spermatozoa against cold shock. 


\section{Materials and Methods}

Semen was collected from 4 rams by electrical stimulation by the method of Blackshaw (1954b) and maintained at $24^{\circ} \mathrm{C}$ during transfer to the laboratory. Samples with high sperm motility were diluted in 5 volumes of $\mathrm{Ca}^{2+}$-free Krebs-Ringer phosphate buffer (Umbriet, Burris \& Stauffer, 1964) and centrifuged for $10 \mathrm{~min}$ at $500 \mathrm{~g}$ and $25^{\circ} \mathrm{C}$. The spermatozoa were resuspended gently in $5 \mathrm{ml}$ of the same buffer and centrifuged again. The washed spermatozoa were then resuspended in Krebs-Ringer phosphate buffer containing $5 \mathrm{~mm}$-glucose to give a sperm concentration of $2.5 \times 10^{8} \mathrm{cell} \mathrm{ml}^{-1}$. Spermatozoa were counted in a haemocytometer.

Washed spermatozoa, with and without added phospholipid, were cold shocked by placing 3 drops of the suspension into glass vials maintained at $0^{\circ} \mathrm{C}$ in an ice bath. Motility was estimated on a scale of 0 to 4 (Emmens, 1947) and the percentage of motile spermatozoa was estimated to the nearest $10 \%$ in a small drop of diluted sperm suspension on a warmed slide. The motility index was calculated from the product of the motility score and the percentage of motile spermatozoa.

To prepare the exogenous phospholipid for sperm suspension, egg-yolk phosphatidylcholine (200 $\mathrm{mg}$ ) and dimyristoylphosphatidylcholine $(20 \mathrm{mg}$ ) (both from Sigma Chemical Co., St Louis, Missouri, U.S.A.) in chloroform were taken to dryness by vacuum desiccation. Water ( 20 $\mathrm{ml}$ ) was added to the dry phospholipid and the preparation was dispersed under nitrogen using an ultrasonic oscillator (Mullard Measuring and Scientific Equipment Ltd, London) for $10 \mathrm{~min}$ at $20 \mathrm{kHz}$. The phospholipid dispersion was centrifuged at $10000 \mathrm{~g}$ for $15 \mathrm{~min}$ to remove large undispersed aggregates of lipid and titanium dislodged from the sonicator probe.

Exogenous phospholipid was removed from sperm suspensions by rewashing; an aliquot of the sperm suspension was centrifuged and the supernatant was replaced by Krebs-Ringer phosphate containing glucose. Lipid was extracted from washed spermatozoa by the method of Folch, Lees \& Sloane-Stanley (1957). Fatty acyl residues of the phospholipids were transmethylated and separated by gas chromatography (Vigo, Goni, Quinn \& Chapman, 1978). Phospholipid phosphorus was assayed after perchloric acid digestion by the method of Owens \& Hughes (1970). Cholesterol was estimated by the colorimetric method of Rudel \& Morris (1973).

\section{Results and Discussion}

The addition of a sonicated preparation of phosphatidylcholine to washed ram spermatozoa protected them from damage due to cold shock as judged by the effect on motility (Table 1). Higher concentrations of phospholipid $(1 \mathrm{mg} / \mathrm{ml}$ compared with $0.5 \mathrm{mg} / \mathrm{ml}$ ) provided more effective protection against cold shock and this was most evident immediately after adding the lipid dispersion. During incubation of the spermatozoa in the presence of phosphatidylcholine the susceptibility of the spermatozoa to cold shock increased and after incubation at $37^{\circ} \mathrm{C}$ for $3 \mathrm{~h}$ no protection by the phospholipid was observed (Table 1). Despite the high rate of motility sustained by the unshocked control preparation, the results imply that the spermatozoa undergo some subtle change during incubation at $37^{\circ} \mathrm{C}$ independent of the presence of the phospholipid. Furthermore, incubation for prolonged periods in the presence of high concentrations of phospholipid may itself be detrimental to the spermatozoa due to the production of lysophosphatides and other breakdown products of the lipid.

To examine the mechanism whereby phospholipid dispersions protect spermatozoa against cold-shock damage the spermatozoa were washed after adding lecithin dispersions and again the effect of rapid cooling on motility was observed. The motility data summarized in Table 2 confirmed that the exogenous phospholipid provided immediate protection against cold shock. Washing the spermatozoa rendered the cells susceptible to cold shock, suggesting that, if the 
effect of the exogenous phospholipid is mediated through an interaction with the plasma membrane of the spermatozoon, then the interaction must be relatively weak and capable of disruption by the mild washing procedure employed.

Table 1. The susceptibility of washed ram spermatozoa to cold shock after incubation at $37^{\circ} \mathrm{C}$ with exogenous phospholipid

\begin{tabular}{lrrr}
\hline & \multicolumn{3}{c}{ Incubation time (h) } \\
\cline { 2 - 4 } Treatment & \multicolumn{1}{c}{0} & 1 & 3 \\
\hline Unshocked control; no phospholipid & $235 \pm 13$ & $235 \pm 13$ & $193 \pm 18$ \\
Cold shocked; no phospholipid & $6 \pm 2$ & $53 \pm 7$ & $5 \pm 0$ \\
Cold shocked; $0.5 \mathrm{mg} / \mathrm{ml}$ phospholipid & $116 \pm 26$ & $83 \pm 12$ & $17 \pm 3$ \\
Cold shocked; $1.0 \mathrm{mg} / \mathrm{ml}$ phospholipid & $175 \pm 36$ & $90 \pm 17$ & $17 \pm 3$ \\
\hline
\end{tabular}

Values represent the mean motility index \pm s.e. of $4(0 \mathrm{~h})$ or $3(1$ and $3 \mathrm{~h})$ observations. The motility index was calculated by multiplying the mean motility score (maximum 4 ) over the observation period by the mean percentage of motile spermatozoa.

Table 2. The protective effect of exogenous phospholipid against cold shock in washed ram spermatozoa and its abolition by rewashing the spermatozoa free of exogenous phospholipid

\begin{tabular}{|c|c|c|c|c|c|c|c|c|c|}
\hline \multirow[b]{3}{*}{ Treatment } & \multicolumn{9}{|c|}{ Exogenous phospholipid conc. $(\mathrm{mg} / \mathrm{ml})$} \\
\hline & \multicolumn{3}{|c|}{0} & \multicolumn{3}{|c|}{0.5} & \multicolumn{3}{|c|}{$1 \cdot 0$} \\
\hline & $\begin{array}{l}\text { Motility } \\
\text { score }\end{array}$ & $\begin{array}{c}\% \\
\text { motile }\end{array}$ & $\begin{array}{l}\text { Motility } \\
\text { index }\end{array}$ & $\begin{array}{l}\text { Motility } \\
\text { score }\end{array}$ & $\begin{array}{c}\% \\
\text { motile }\end{array}$ & $\begin{array}{l}\text { Motility } \\
\text { index }\end{array}$ & $\begin{array}{l}\text { Motility } \\
\text { score }\end{array}$ & $\begin{array}{c}\% \\
\text { motile }\end{array}$ & $\begin{array}{c}\text { Motility } \\
\text { index }\end{array}$ \\
\hline Unshocked & $4 \cdot 0 \pm 0$ & $59 \pm 3$ & $235 \pm 13$ & $4 \cdot 0 \pm 0$ & $63 \pm 3$ & $250 \pm 10$ & $4 \cdot 0 \pm 0$ & $63 \pm 5$ & $250 \pm 19$ \\
\hline Cold shocked & $1 \cdot 1 \pm 0 \cdot 1$ & $6 \pm 2$ & $6 \pm 2$ & $2.9 \pm 0.5$ & $40 \pm 4$ & $116 \pm 26$ & $3 \cdot 3 \pm 0 \cdot 3$ & $53 \pm 6$ & $175 \pm 36$ \\
\hline $\begin{array}{l}\text { Cold shocked } \\
\text { after } \\
\text { rewashing }\end{array}$ & $0.6 \pm 0.2$ & $6 \pm 5$ & $6 \pm 5$ & $1 \cdot 1 \pm 0.5$ & $8 \pm 4$ & $15 \pm 12$ & $1 \cdot 3 \pm 0 \cdot 4$ & $10 \pm 5$ & $19 \pm 15$ \\
\hline
\end{tabular}

Mean values \pm s.e.m. for 4 observations.

Chemical analysis of the spermatozoa after exposure to exogenous phospholipid consisting of egg yolk-phosphatidylcholine and dimyristoylphosphatidylcholine indicated that there was no association of this phospholipid with the spermatozoa (Table 3) as the phospholipid content of the rewashed cells did not increase even when exposed to $1 \mathrm{mg}$ exogenous phospholipid $/ \mathrm{ml}$ for up to $3 \mathrm{~h}$. However, Evans \& Setchell (1978) reported almost instantaneous association of phosphatidylcholine liposomes with ram spermatozoa.

Normal ram spermatozoa have very little myristic acid in their phospholipids (Poulos et al., 1973) and dimyristoyllecithin was, therefore, included in the exogenous phospholipid as a marker to check fusion of the liposomes with the spermatozoa. Fatty acid analysis of the spermatozoa, however, showed no increase in the proportion of myristoyl $\left(C_{14: 0}\right)$ to palmitoyl $\left(C_{16: 0}\right)$ esters when the washed spermatozoa were incubated with the exogenous phospholipid mixture: the ratio of $C_{14: 0}$ to $C_{16: 0}$ was 1.04 at $0 \mathrm{~h}$ and 0.73 at $3 \mathrm{~h}$. The immediate protection afforded against cold shock by exogenous phospholipid further argues against a slow exchange of membrane components between the spermatozoa and the liposomes.

Incubation of egg-yolk lecithin liposomes with biological membranes or bilayers containing cholesterol is known to cause movement of cholesterol from the cholesterol-containing membranes to the liposomes until the concentration gradient is abolished (Hope, Bruckdorfer, Hart \& Lucy, 1977). To check if removal of cholesterol was responsible for the increase in 
susceptibility of the spermatozoa during incubation with phospholipid dispersions, the cholesterol content of the spermatozoa was also determined at intervals during the $3 \mathrm{~h}$ incubation (Table 3). There was no consistent decrease in the cholesterol to phospholipid ratio of washed sperm preparations. Nevertheless, because the plasma membrane represents only a small proportion of the total cell membranes some alteration may have taken place but remained undetected.

Table 3. Phospholipid and cholesterol content of washed ram spermatozoa after incubation with exogenous phospholipid

\begin{tabular}{|c|c|c|c|c|c|c|}
\hline \multirow{3}{*}{$\begin{array}{l}\text { Incubation } \\
\text { time } \\
\text { (h) }\end{array}$} & \multicolumn{6}{|c|}{ Exogenous phospholipid conc. (mg/ml) } \\
\hline & \multicolumn{2}{|c|}{0} & \multicolumn{2}{|c|}{0.5} & \multicolumn{2}{|c|}{1.0} \\
\hline & Phospholipid & Cholesterol & Phospholipid & Cholesterol & Phospholipid & Cholesterol \\
\hline 0 & $\begin{array}{l}1.59 \\
2.36\end{array}$ & $\begin{array}{l}367 \\
431\end{array}$ & $\begin{array}{l}1.55 \\
1.75\end{array}$ & $\begin{array}{l}282 \\
396\end{array}$ & $\begin{array}{l}1.14 \\
1.47\end{array}$ & $\begin{array}{l}468 \\
443\end{array}$ \\
\hline 1 & $\begin{array}{l}2 \cdot 16 \\
2 \cdot 12\end{array}$ & $\begin{array}{l}468 \\
386\end{array}$ & $\begin{array}{l}2 \cdot 16 \\
2 \cdot 16\end{array}$ & $\begin{array}{l}450 \\
468\end{array}$ & $\begin{array}{l}1.39 \\
1.34\end{array}$ & $\begin{array}{l}443 \\
418\end{array}$ \\
\hline 2 & $\begin{array}{l}1.71 \\
2.00\end{array}$ & $\begin{array}{l}353 \\
383\end{array}$ & $\begin{array}{l}1.30 \\
1.67\end{array}$ & $\begin{array}{l}308 \\
361\end{array}$ & $\begin{array}{l}1.34 \\
1.55\end{array}$ & $\begin{array}{l}318 \\
390\end{array}$ \\
\hline 3 & $\begin{array}{l}2 \cdot 40 \\
2 \cdot 20\end{array}$ & $\begin{array}{l}443 \\
420\end{array}$ & $\begin{array}{l}2 \cdot 00 \\
2 \cdot 20\end{array}$ & $\begin{array}{l}499 \\
537\end{array}$ & $\begin{array}{l}1.87 \\
2.04\end{array}$ & $\begin{array}{l}569 \\
530\end{array}$ \\
\hline Mean & 2.07 & 407 & 1.85 & 413 & 1.52 & 448 \\
\hline
\end{tabular}

Phospholipid ( $\mu \mathrm{mol} / 10^{9}$ spermatozoa) and cholesterol ( $\mu \mathrm{g} / 10^{9}$ spermatozoa) values are for duplicate estimations.

The present study indicates that the primary membrane lesion associated with cold-shock damage is the plasma membrane and that alteration of acrosomal and mitochondrial membranes (Quinn et al., 1969) are subsidiary events. The presence of exogenous phospholipid prevents this damage, possibly by occupying sites on the plasma membrane surface. A similar loose association between components of egg yolk with the plasma membrane of ram spermatozoa to prevent cold-shock damage has been suggested on the basis of the binding of the fluorescent probe, 1-anilino naphthalene 8-sulphonic acid, to the spermatozoon (Watson, 1975). Unfortunately, the conclusions drawn from the above study were not unambiguous because partition of the probe into the egg-yolk component was not taken into account. The present study has, however, confirmed by chemical analysis that the exogenous phospholipid can be removed by washing the spermatozoa twice, thereby causing loss of the protection against cold shock. The consequences of interaction of liposomes with the cell surface and the reason why the spermatozoa are protected from chilling injury are unknown.

This work was financially assisted by the Australian Research Grants Committee and the Australian Wool Corporation.

\section{References}

Blackshaw, A.W. (1954a) The prevention of temperature shock of bull and ram semen. Aust. J. biol. Sci. 7, 573-582.

Blackshaw, A.W. (1954b) A bipolar rectal electrode for the production of ejaculation in sheep. Aust. vet. J. 30, 249-250.

Bruckdorfer, R.K., Graham, J.M. \& Green, C. (1968)
The incorporation of steroid molecules into lecithin sols., $\beta$-lipoproteins and cellular membranes. Eur. $J$. Biochem. 4, 512-518.

Darin-Bennett, A. \& White, I.G. (1977) Influence of the cholesterol content of mammalian spermatozoa on susceptibility to cold shock. Cryobiology 14, 466470 . 
Darin-Bennett, A., Poulos, A. \& White, I.G. (1974) The phospholipids and phospholipid-bound fatty acids and aldehydes of dog and fowl spermatozoa. $J$. Reprod. Fert. 41, 471-474.

Emmens, C.W. (1947) The motility and viability of rabbit spermatozoa at different hydrogen ion concentrations. J. Physiol., Lond. 106, 471-481.

Evans, R.W. \& Setchell, B.P. (1978) Association of exogenous phospholipids with spermatozoa. $J$. Reprod. Fert. 53, 357-362.

Folch, J., Lees, M. \& Sloane-Stanley, G.H. (1957) A simple method for the isolation and purification of total lipids from animal tissues. J. biol. Chem. 226, 497-509.

Hope, M.J., Bruckdorfer, R.K., Hart, C.A. \& Lucy, J.A. (1977) Membrane cholesterol and cell fusion of hen and guinea-pig erythrocytes. Biochem. J. 166, 255263.

Madden, T.D., Chapman, D. \& Quinn, P.J. (1979) Cholesterol modulates activity of calcium-dependent ATPase of the sarcoplasmic reticulum. Nature, Lond. 279, 538-541.

Owens, K. \& Hughes, B.P. (1970) Lipids of dystrophic mouse muscle; whole tissue and particulate fractions. J. Lipid Res. 11, 486-495.

Poulos, A., Darin-Bennett, A. \& White, I.G. (1973) The phospholipid-bound fatty acids and aldehydes of mammalian spermatozoa. Comp. Biochem. Physiol. 46, 541-549.

Quinn, P.J., White, I.G. \& Cleland, K.W. (1969) Chemical and ultrastructural changes in ram spermatozoa after washing, cold shock and freezing. J. Reprod. Fert. 18, 209-220.

Rudel, L.L. \& Morris, M.D. (1973) Determination of cholesterol using 0 -phthalaldehyde. J. Lipid Res. 14, 364-366.

Umbriet, W.W., Burris, R.H. \& Stauffer, J.F. (1964) Manometric Techniques, pp. 132-133. Burgess, Minneapolis.

Vigo, C., Goni, F.M., Quinn, P.J. \& Chapman, D. (1978) The modulation of membrane fluidity by hydrogenation process. II. Homogeneous catalysis and model biomembranes. Biochim. Biophys. Acta 508, 1-14.

Watson, P.F. (1975) The interaction of egg yolk and ram spermatozoa studies with a fluorescent probe. $J$. Reprod. Fert. 42, 105-111.

Received 15 March 1980 